\title{
DETECTION OF PESTICIDE RESIDUES AND HEAVY METALS IN WHEAT SAMPLES COLLECTED FROM LOCAL MARKETS IN DIFFERENT EGYPTIAN GOVERNORATES \\ El-Zemaity, M. S. ${ }^{1}$; M. A. El-Hashash ${ }^{2}$; Mona A. Khorshed ${ }^{3}$ and Ghada A. Ali ${ }^{3}$ \\ ${ }^{1}$ Plant Protection Department - Faculty of Agriculture - Ain Shams University \\ ${ }^{2}$ Chemistry Department - Faculty of Science - Ain Shams University \\ ${ }^{3}$ Central Laboratory of Residue Analysis of Pesticides and Heavy Metals in Food - Agricultural Research Centre
}

\section{ABSTRACT}

One hundred and fifty five wheat samples were collected from different local markets located in ten governorates in Egypt. All samples were subjected to multiresidue analysis to investigate the residues of organochlorine, organophosphorous, organonitrogen and some pyrethroids. However, only eighty three samples were subjected to heavy metals analysis to investigate lead $(\mathrm{Pb})$, cadmium $(\mathrm{Cd})$, and copper $(\mathrm{Cu})$ levels. In multiresidue analysis, results showed that $60.6 \%$ of all samples analyzed had no detectable pesticide residues, while $39.4 \%$ of samples were contaminated with one or more than pesticide residue of malathion, chlorpyrifos-me, pirimiphos-methyl, fenitrothion, chlorpyrifos and diniconazole. Also, malathion recorded the highest contamination and violation percentages, where $37.4 \%$ of the total number of samples analyzed were contaminated and only $2.6 \%$ of samples exceeded the malathion Maximum Residue Limit (MRL) established by Codex Alimentarius Commission on Pesticide Residues (CCPR) $(0.5 \mathrm{mg} / \mathrm{kg}$ ). In heavy metals analysis, the results revealed that all analyzed samples were contaminated with at least one of the three investigated elements $(\mathrm{Cd}, \mathrm{Pb}$, and $\mathrm{Cu})$, where the contamination percentage was $100 \%$, of which $18.1 \%$ exceeded the Maximum Limits (ML's) of the detected elements. Copper was the most frequently detected element, followed by cadmium, and the lowest was lead. Keywords: pesticide residues, heavy metals, wheat, detection, Egypt.

\section{INTRODUCTION}

Wheat (Triticum spp.) (Johnson and Manske 1977) is a grass that is cultivated worldwide. Globally, it is an important human food grain ranking second in total production as a cereal crop behind maize; the third being rice (Mukherjee et al., 1980). One third of wheat grain yield is consumed by milling and baking mainly for the production of bread which is an important component of every day diet in many countries.

Wheat grain is a staple food used to make flour for leavened, flat and steamed breads; cookies, cakes, pasta, noodles and couscous (Fytianos et al., 1985); and for fermentation to make beer (Vaidya et al., 1991), alcohol, vodka (Battu et al., 1996) or biofuel (Abou-Arab et al., 1999). Wheat is planted to a limited extent as a forage crop for livestock, and the straw can be used as fodder for livestock or as a construction material for roofing thatch 
(Correia et al., 2000; Abou-Arab and Abou Donia2001).

The wide spread contamination of pesticide residues in food is due to their extensive applications in agriculture to control pests during pre- and post-harvest practices. Most commonly used pesticides for protecting wheat grain against insects attack during storage are organophosphate pesticides (Arthur, 1992; Arthur, 1996; Stathers et al., 2002; Lalah and Wandiga, 2002), synthetic pyrethroids (Weidner, 1989; Athanassiou et al., 2004) and fungicides (Ahmed, 2001). The wide spread contamination of organochlorine pesticide residues in food is due to either their direct applications or more importantly industrial emission in environment.

The key disease, pest, growth and storage problems in cereals may require the use of pesticides. Only those cereal problems which result in residues or require treatment relatively close to harvest and therefore have a greater risk of leaving residues have been included. The problems are rated for their importance according to their effect on crop yield and also for the occurrence of residues that might arise from the use of pesticides to control the problem.

On the light of increasing reports on pesticide contamination of food commodities (Johnson and Manske 1977); Mukherjee et al., 1980; Fytianos et al., 1985; Vaidya et al., 1991; Battu et al., 1996; and Abou-Arab et al., 1999) consumers and buyers are becoming more aware of the importance of safe and high quality food products (Correia et al., 2000 and Giannou et al., 2003).

Also, heavy metals are among the most frequently encountered contaminants in the environment. Several reports have focused on the residues of numerous heavy metals in foodstuffs (Cabrera et al., 1995; Llobet et al., 1998). Other reports have delineated on the contamination of the cereal products; including bread with heavy metals. (Hubbard and Lindsay, 1979) reported that the major route of man's exposure to heavy metal was ingestion. Even in the case of lead, where the use of leaded petrol products, ambient lead levels comes higher than other heavy metals pollutants, direct inhalation contributes less to the total body burden than ingested lead. The main contributors, therefore, to heavy metals in the body were the foods consumed.

The aim of this study is to investigate the levels of pesticide residues and some heavy metals $(\mathrm{Cu}, \mathrm{Cd}$, and $\mathrm{Pb}$ ) in wheat samples collected from different governorates located in Egypt.

\section{MATERIALS AND METHODS}

Sampling:

A total of one hundred and fifty five wheat samples were collected from the local markets or retail shops in ten Egyptian governorates (Beni Seuef, Cairo, Damietta, Fayoum. Gharbiya, Giza, Ismalia, Minufiya, Qalyubiya and Sharkyia,). Each sample weighed one kilogram as a result of four subsamples $250 \mathrm{gm}$ each from different wheat bags. Samples were mixed, grinded and homogenized using an electrical apparatus (Bamix - with platinum cutter) according to the Codex Guidelines vol. 2; 1993 to give a 
representative sample of fine grinded wheat. Analysis of samples was carried out directly on their arrival to the laboratory or they were stored at $0-5^{\circ} \mathrm{C}$.

Sample Analysis:

All reference pesticides were certified standards and were provided by Dr. Ehrenstorfer Gmbh, Gogginer str. 78 D-8900 Augoburg. Germany, and by the FAO (Food Agriculture Organization of the United Nations, Rome, Italy and were prepared in $\mathrm{n}$-hexane / acetone mixture (9:1).

Metals stock standards of $\mathrm{Cu}, \mathrm{Pb}$ and $\mathrm{Cd}$ were Merck $1000 \mathrm{mg} / \mathrm{L}$. For AAS, the intermediate and working solutions of $\mathrm{Cd}, \mathrm{Pb}$, and $\mathrm{Cu}$ prepared from stock solution with different concentrations in $0.3 \% \mathrm{HNO}_{3}$.

\section{Pesticide Residue Analysis}

Extraction and Clean-up

According to the method described by (Luck et al., 1981), pesticide residues were extracted from grinded dry samples (wheat samples) by blending with acetone and distilled water. A large number of pesticide residues cross from the aqueous filtrate into the organic phase by shaking with petroleum ether and dichloromethane. The clean up step was carried out as described by (Suzuki et al., 1979) using a florisil column. Organic phase was concentrated just to dryness and dissolved in hexane/acetone; 9:1 for GC detection. This method allows the determination of 80 pesticide residues. Table (1) shows the common name and limits of quantification of these pesticides.

Table (1): Analyzed Pesticides and their Limits of Quantification

\begin{tabular}{|c|c|c|c|c|c|c|c|c|}
\hline $\mathbf{S} / \mathbf{N}$ & Pesticide & LOQ & S/N & Pesticide & LOQ & $\mathrm{S} / \mathrm{N}$ & Pesticide & LOQ \\
\hline 1 & Acephate & 0.01 & 28 & Dimethoate & 0.05 & & Omethoate & 0.05 \\
\hline 2 & Alachlor & 0.02 & 29 & Diniconazole & 0.10 & 56 & Oxidiazone & 0.10 \\
\hline 3 & Atrazine & 0.10 & 30 & Edifenfos & 0.02 & 57 & Parathion & 0.05 \\
\hline 4 & Bendiocarb & 0.10 & 31 & Endosulfan-alpha & 0.02 & 58 & Parathion-methy & 0.05 \\
\hline 5 & Bromopropylate & 0.05 & 32 & Endosulfan-beta & 0.02 & 59 & Pendimethalin & 0.10 \\
\hline 6 & Carbaryl & 0.50 & 33 & Endosulfan sulphate & 0.10 & 60 & Permethrin & 0.10 \\
\hline 7 & Carbosulfan & 0.10 & 34 & Endrin & 0.10 & 61 & Phenthoate & 0.10 \\
\hline 8 & Captan & 0.10 & 35 & Ethion & 0.10 & 62 & Phosalone & 0.05 \\
\hline 9 & Chlorothalonil & 0.02 & 36 & Fenamiphos & 0.02 & 63 & Phosphamidone & 0.10 \\
\hline 10 & Chlorpyrifos & 0.02 & 37 & Fenitrothion & 0.05 & 64 & Pirimicarb & 0.05 \\
\hline 11 & Chorpyrifos-methyl & 0.05 & 38 & Fenpropathrin & 0.05 & 65 & Pirimiphos-ethyl & 0.02 \\
\hline 12 & Chlordane-cis & 0.02 & 39 & Fenthion & 0.01 & 66 & Pirimiphos-me & 0.05 \\
\hline 13 & Chlordane-trans & 0.02 & 40 & Fenvalerate & 0.01 & 67 & Procymidone & 0.05 \\
\hline 14 & Cyanophos & 0.05 & 41 & $\mathrm{HCH}$-alpha & 0.02 & 68 & Profenofos & 0.02 \\
\hline 15 & Cyfluthrin & 0.10 & 42 & $\mathrm{HCH}$-beta & 0.01 & 69 & Promicarb & 0.10 \\
\hline 16 & Cypermethrin & 0.10 & 43 & $\mathrm{HCH}$-delta & 0.02 & 70 & Propiconazole & 0.10 \\
\hline 17 & Lambadacyhalothrin & 0.10 & 44 & $\begin{array}{l}\mathrm{HCH}- \\
\text { gamma(lindane) }\end{array}$ & 0.01 & 71 & Prothiofos & 0.02 \\
\hline 18 & Chlorpropham & 0.50 & 45 & Heptachlor & 0.01 & 72 & Pyrazophos & 0.02 \\
\hline 19 & DDD-p,p & 0.02 & 46 & Heptachlor epoxide. & 0.01 & 73 & Tebuconazole & 0.10 \\
\hline 20 & DDE-p,p & 0.02 & 47 & Hexachlorobenzene & 0.01 & 74 & Tetradifon & 0.03 \\
\hline 21 & DDT-o,p & 0.02 & 48 & Imazailil & 0.50 & 75 & Tolcophos-me & 0.02 \\
\hline 22 & DDT-p,p & 0.02 & 49 & Iprodion & 0.02 & 76 & Triadmefon & 0.05 \\
\hline 23 & Deltamethrin & 0.20 & 50 & Malathion & 0.20 & 77 & Triadimenol & 0.10 \\
\hline 24 & Diazinon & 0.05 & 51 & Metalaxyl & 0.05 & 78 & Triazophos & 0.02 \\
\hline 25 & Dichlofluanid & 0.05 & 52 & Metamidiphos & 0.10 & 79 & Trifluraline & 0.01 \\
\hline 26 & Dicofol & 0.02 & 53 & Metrtibuzin & 0.05 & 80 & Vinclozolin & 0.01 \\
\hline 27 & Dieldrin & 0.01 & 54 & Monocrotop & & & & \\
\hline
\end{tabular}




\section{Quality Assurance procedures:}

All analytical methods and instructions were carefully validated as a part of the laboratory quality assurance system and were audited and accredited by the Center of Metrology and Accreditation Finnish Accreditation Service (FINAS) ISO/IEC Guide 25. The criteria of quality assurance were described in (Dogheim et. al.2002). The recoveries were between $70-120 \%$ and CV less than $20 \%$. Low level fortification of all samples with the contaminants of interest has been carried out to ensure that the method performed satisfactory for the particular food examined. Analysis of duplicate of samples represents precision of analysis.

\section{Determination}

All analytical methods and instruments were fully validated as a part of the laboratory quality assurance system and were audited and accredited by the Center of Metrology and Accreditation Finnish Accreditation Services (FINAS) under the requirements of ISO 17025. The criteria of quality assurance were described in (Dogheim et al., 2002). The recoveries were between $70-120 \%$ and coefficient of variation was less than $20 \%$. Fortification of wheat samples with the contaminants under study has been carried out to ensure that the method performed satisfactory for the particular commodity examined. Analysis of duplicate samples represents precision of analysis.

Qualitative and quantitative determination of pesticide residues was carried out using gas liquid chromatographic technique (GLC technique). The used gas chromatographs were Agilent 6890 series; one equipped with double electron capture detector (ECD) to detect organochlorine and pyrethroids residues and the other with double nitrogen phosphorus detector (NPD) to detect organonitrogen and organophosphorus residues; both GCECD and GC-NPD have the following parameters:

\section{Columns:}

Column-A; Agilent Technologies PAS-5 (5\% diphenyl and 95\% dimethylpolysiloxane) with internal diameter $0.32 \mathrm{~mm}$, film thickness $0.52 \mathrm{um}$, column length $25 \mathrm{~m}$, phase ratio 150 , nitrogen flow rate $1.5 \mathrm{ml} / \mathrm{min}$ carrier, total flow (carrier + makeup) $55 \mathrm{ml} / \mathrm{min}$.

Column-B; Agilent Technologies PAS-1701 (14\% cyanophenyl methylpolysiloxane) with internal diameter $0.32 \mathrm{~mm}$, film thickness $0.25 \mathrm{um}$, column length $30 \mathrm{~m}$, phase ratio 150 , nitrogen flow rate $1.3 \mathrm{ml} / \mathrm{min}$ carrier, total flow (carrier + makeup) $55 \mathrm{ml} / \mathrm{min}$. septum purge $3 \mathrm{ml} / \mathrm{min}$, purge flow 50 $\mathrm{ml} / \mathrm{min}$, purge time $0.7 \mathrm{~min}$, air flow $60 \mathrm{ml} / \mathrm{min}$.

- Oven program: initial temperature $90^{\circ} \mathrm{C}$ for $2 \mathrm{~min}$; ramp (1) $20\left({ }^{\circ} \mathrm{C} / \mathrm{min}\right)$ to $150^{\circ} \mathrm{C}$, ramp (2) $6\left({ }^{\circ} \mathrm{C} / \mathrm{min}\right)$ to $270^{\circ} \mathrm{C}$ hold $15 \mathrm{~min}$.

- injector temperature $225^{\circ} \mathrm{C}$, detector temperature $280 \stackrel{\circ}{\circ}$, where detector A: make up gas $\left(\mathrm{N}_{2}\right)$ flow rate $8 \mathrm{ml} / \mathrm{min}, \mathrm{H}_{2}$ flow rate $4.5 \mathrm{ml} / \mathrm{min}$., detector B: make up gas $\left(\mathrm{N}_{2}\right)$ flow rate $6 \mathrm{ml} / \mathrm{min}, \mathrm{H}_{2}$ flow rate $4.8 \mathrm{ml} / \mathrm{min}$., septum purge $5 \mathrm{ml} / \mathrm{min}$, splitless time $0.75 \mathrm{~min}$, purge flow $34 \mathrm{ml} / \mathrm{min}$.

\section{Heavy metals analysis}

\section{Digestion}

The analytical methodology used was that described in the thesis of (NMKL, 1991). The sample was digested by wet digestion technique using concentrated nitric acid in a digestor (Techetor, 2020), and the digestion 
residue dissolved into $0.3 \% \mathrm{HNO}_{3} .(0.5-1 \mathrm{~g})$ of dried samples were transferred to glass digestion tubes, (1-2) $\mathrm{ml}$ distilled water added and $10 \mathrm{ml}$ of conc. $\mathrm{HNO}_{3}$. The solutions were boiled for 72 hours. The nitric acid solution was evaporated almost to dryness and the residue was transferred with $0.3 \% \mathrm{HNO}_{3}$ to $25 \mathrm{ml}$ volumetric flask.

\section{Quality control procedure:}

All analytical methods and instruments were fully validated as a part of the laboratory quality assurance system and were audited and accredited by the Center of Metrology and Accreditation Finnish Accreditation Services (FINAS) ISO/IEC Guide 25. The criteria of quality assurance described in (Dogheim et a.l 2002). The recoveries were between $70-120 \%$ and CV less the $20 \%$. Fortification of all samples with the contaminants of interest has been carried out to ensure that the method performed satisfactory for the particular food examined. Analysis of duplicate samples represents precision of analysis. Limits of Quantification were the limit of quantification of lead, cadmium, and copper was $0.04,0.002$, and $0.5(\mathrm{mg} / \mathrm{kg})$, respectively.

\section{Determination}

Cadmium, copper, and lead were determined by Atomic Absorption Spectroscopy (AAS), using deuterium lamp for background correction. The used Atomic absorption spectrometer was (Analytical technology, INC, Unicam 929) equipped with graphite furnace with auto sampler and flame atomic absorption. Typical furnace parameters for $\mathrm{Cd}$ and $\mathrm{Pb}$ in AAS are given in table (2).

Table (2): Typical furnace parameters for $\mathrm{Cd}$ and $\mathrm{Pb}$ in AAS

\begin{tabular}{|l|c|c|c|c|}
\hline \multicolumn{1}{|c|}{ Step } & Temp. (oC) & Time (sec) & $\begin{array}{c}\text { Ramp } \\
\text { (oC/sec) }\end{array}$ & $\begin{array}{c}\text { Gas flow } \\
\text { (ml/min) }\end{array}$ \\
\hline Drying & 120 & 40 & $30(\mathrm{Cd}), 10(\mathrm{~Pb})$ & 2 \\
\hline Ashing & 800 & 20 & 50 & 2 \\
\hline Atomization & 1800 & 3 & 0 & 0 \\
\hline Cleaning & 2500 & 3 & 0 & 2 \\
\hline Cooling & 20 & 5 & 0 & 2 \\
\hline
\end{tabular}

\section{RESULTS AND DISCUSSION}

\section{Pesticide residues analysis:}

Table (3) listed the number of samples analyzed, as well as the percentage of the samples that contained detectable pesticide residues, also their minimum, maximum and mean concentrations, number and percentage of samples that exceeded the MRL's established for pesticide.

Overall, $60.6 \%$ of all samples analyzed had no detectable pesticide residues, while $39.4 \%$ of samples were contaminated with one or more than pesticide residues, of which $2.6 \%$ was violated. The detected pesticides were malathion, chlorpyrifos-me, pirimiphos-me, fenitrothion, diniconazole, and chlorpyrifos. The most frequently detected pesticides in decreasing order of frequency percentage were malathion (37.4\%), chlorpyrifos-me $(10.3 \%)$, pirimiphos-me (1.94\%), fenitrothion, chlorpyrifos, and diniconazole $(0.65 \%)$. Malathion detected in 58 wheat samples $(37.4 \%)$, with mean values ranged 
from $(0.05$ to $1.25 \mathrm{mg} / \mathrm{kg})$. The mean concentration of chlorpyrifos -me varied from $(0.05-0.29 \mathrm{mg} / \mathrm{kg})$.

Also, data showed that the highest contamination percentage observed in the wheat samples collected from El-Fayuom governorate $(75 \%)$, followed by Giza governorate (64\%), and then by Ismalia. However the lowest contamination percentage recorded in the samples collected from Minufiya governorate (12.5\%).

Concerning health hazards, the Maximum Residue Limits (MRL's) for malathion on wheat established by Codex Alimentarius Commission on Pesticide Residues (CCPR, 2005) are $0.5 \mathrm{mg} / \mathrm{kg}$. The violations of the malathion Maximum Residue Limits (MRL's) were observed in only four samples (i.e. $2.6 \%$ of 155 total number of samples analyzed). The highest percentage of violations occurred in three wheat samples collected from Giza (10\% of total no. of samples analyzed, 48) and in one sample which collected from Qalybiya governorate.

In general, one would expect the higher residue concentrations for those pesticides used close to or at harvest, as well as lower residue concentrations would be expected for treatments earlier in the season. The causes of violations may be due to compliance with pre-harvest interval for the different pesticides may be causing the violations. A violative sample doesn't necessary imply a health risk since the (MRL's) is based on a lifetime of exposure and incorporates a large safety margin.

Pirimicarb, finitrothion and malathion are the recommended pesticides on the wheat crop according to the agriculture recommendations (2001). The contamination of wheat with such pesticide residues may be either due to their direct use for protecting wheat plants at field and grains at storage conditions or indirectly from the contaminated environmental sources. 
J. Plant Prot. and Path., Mansoura Univ., Vol. 3 (3), March, 2012 
El-Zemaity, M. S. et al. 


\section{Heavy metals analysis:}

Table (4) shows the minimum, maximum, and mean concentration levels of $\mathrm{Cd}, \mathrm{Pb}$, and $\mathrm{Cu}$ contaminants, and also, the contaminated samples number and percentage, the violated elements and samples, detected in eighty three samples of wheat collected from different Egyptian local markets located in ten governorates.

The results listed in table (4) revealed that all the analyzed samples, collected from different governorates, contaminated with at least one of the three investigated elements $(\mathrm{Cd}, \mathrm{Pb}$, and $\mathrm{Cu})$, and the contamination percentage was $100 \%$, of which $18.1 \%$ of all samples analyzed exceeded the maximum limits of the detected elements. The copper was the most frequently detected element in the analyzed samples, where the contamination percentage was $100 \%$. However, $95.2 \%$ of all samples analyzed were contaminated with cadmium $(\mathrm{Cd})$. The lead $(\mathrm{Pb})$ was detected in only $57.8 \%$ of the total samples analyzed but had the highest violation percentage, where its levels were exceeded in only fifteen samples (i.e violation percentage was $18.1 \%$ of the total samples analyzed). However, the cadmium levels were exceeded in only two samples (i.e. violation percentage was $2.4 \%$ of the total samples analyzed).

Today, foodstuff and water are the basic sources for daily lead intake for adults and children. Table (4), demonstrates that lead $(\mathrm{Pb})$ concentration ranged from $(0.04$ to $4.8 \mathrm{mg} / \mathrm{kg})$. The highest mean concentration of $\mathrm{Pb}$ recorded in the samples collected from El- Sharkyia $(4.8 \mathrm{mg} / \mathrm{kg})$, followed by El- Qalyuibya $(0.24 \mathrm{mg} / \mathrm{kg})$. However, the lowest mean value $(0.1 \mathrm{mg} / \mathrm{kg})$ was detected in the samples collected from El- Minufiya governorate.

Also, data showed that the highest contamination percentage $(100 \%)$ of $\mathrm{Pb}$ was recorded in the samples collected from (Beni Suef, El-Fayoum, ElMinufiya, and El-Sharkyia governorates. While, the lowest contamination percentage was detected in the samples collected from Giza governorate (45.7\%). Also, all samples collected from Damietta were free from $\mathrm{Pb}$ contaminate. On the other hand, the levels of $\mathrm{Pb}$ exceeded its established maximum limit $(0.2 \mathrm{mg} / \mathrm{kg})$, in fifteen samples, out of 83 total number of samples analyzed (i.e. $18.1 \%$ ), five samples from Cairo governorate (i.e. the violation percentage was $25 \%$ out of 20 samples collected from Cairo), three from Giza governorate (i.e. $8.6 \%$ violation percentage), two from Qalyubiya (i.e. $50 \%$ violation percentage), one from each of Beni Suef, Fayoum, Gharbiya, Ismalia, and Sharkiya governorates, where the violation percentage, calculated relative to the total number of samples analyzed, was $1.2 \%$ for each.

The most probable sources of contamination for lead transferred to the wheat may be due to the presence of lead in the environment because of air, soil, and water pollution. Where, the main sources of the lead pollution in the environment may be industrial production processes and their emissions or liquid effluents, road traffic with leaded petrol, the smoke and dust emissions of coal and gas fired power stations. Also, may be due to the application of some phosphate fertilizers and pesticides contained some lead, mainly as lead arsenate base. 
El-Zemaity, M. S. et al.

4 
J. Plant Prot. and Path., Mansoura Univ., Vol. 3 (3), March, 2012

4

283 
Cadmium is a metal toxic as lead. It is such accumulative poison, and mainly accumulated in kidney and liver in human beings. Food is the major source for cadmium intake of human body (Tati et al., 1976; Biddle, 1982; Dunnick and Fowler, 1988; Robards and Worsfold, 1991). Data showed that most wheat samples collected from all ten governorates were contaminated with $\mathrm{Cd}$ contaminant. The mean cadmium values were varied between 0.002 and $0.25 \mathrm{mg} / \mathrm{kg}$. The highest mean cadmium value was found as 0.062 $\mathrm{mg} / \mathrm{kg}$ in wheat samples obtained from Sharkiya governorate. However, the lowest mean value $(0.011 \mathrm{mg} / \mathrm{kg})$ was recorded in samples collected from El Minufiya and EI - Qalyubiya governorates. Also data showed that the levels of $\mathrm{Cd}$ exceeded the maximum limit $(0.2 \mathrm{mg} / \mathrm{kg})$ established for $\mathrm{Cd}$ in only two samples collected from Cairo governorate, where the violation percentage was $10 \%$ out of 20 collected samples.

The contamination with $\mathrm{Cd}$ may be due to field application of phosphate fertilizers containing $\mathrm{Cd}$ as impurity or due to the biosphere contamination due to its emission in the industrial processes such as batteries, metal melting and refining, coal and oil-fired power stations, electroplating plants, etc.

Copper $(\mathrm{Cu})$ has been recognized as an essential element for many years, due to its presence in important proteins and enzymes. High levels of $\mathrm{Cu}$ can cause acute toxicity. Human deaths have been known to occur from deliberate ingestion of large quantities of copper sulfate. As shown in the table (4), all wheat samples collected from ten governorates were contaminated with $\mathrm{Cu}$, where the contamination percentage was $100 \%$, and the mean copper concentration ranged between 4.1 and $354 \mathrm{mg} / \mathrm{kg}$. The highest mean value of $\mathrm{Cu}(354 \mathrm{mg} / \mathrm{kg})$ was detected in samples collected from El-Sharkiya governorate. While, the lowest mean concentration (4.1 $\mathrm{mg} / \mathrm{kg}$ ) recorded in samples from Beni Suef governorate.

The contamination of wheat samples with copper may be due to the soil or water contamination as a result of the application of fungicides or fertilizers containing $\mathrm{Cu}$.

Reviewing the obtained data of multiresidue analysis, it could be concluded that malathion was the most frequently detected pesticide residue (detected in 58 out of 155 (37.4\%) samples), followed by chlorpyrifos-me (detected in 16 out of 155 (10.3\%) samples). Those compounds are broad spectrum organophosphorous pesticides used against several insect species. Violation was observed in only four samples $(2.6 \%$ of the total samples analyzed), where malathion exceeded its established MRL.

Also, the obtained data in case of heavy metal analysis threw the light on the highest violation percentage recorded by lead $(18.1 \%$ of samples exceeded its maximum limit) in spite of its lowest contamination percentage (57.8\%) compared with $\mathrm{Cd}(95.2 \%)$ and $\mathrm{Cu}(100 \%)$. 


\section{REFERENCES}

Abou-Arab, A. A. K. (2002). Degradation of organochlorine pesticides by meat starter in liquid media and fermented product. Food Chem. Toxicol., 40, 33-41.

Abou-Arab, A. A. K., Kawther Soliman, M. Tantawy El, M. E., Badeaa, I. R. and Khayria, N. (1999). Quantity estimation of some contaminants in commonly used medicinal plants in the Egyptian market. Food Chem., $67,357-363$

Abou-Arab, A. A. K. and Abou Donia, M. A. (2001). Pesticide residue in some Egyptian spices and medicinal plants as affected by processing. Food Chem., 72, 439-445.

Ahmed, F. E. (2001). Analysis of pesticides and their metabolites in food and drinks. Trends Anal. Pesti., 20, 649-660.

Arthur, F. H. (1992). Residual efficacy of chlorpyriphos-methyl bioresmethrin and chlorpyriphosmethyl resmethrin for controlling lesser grain borers (Coleoptera: Bostrichidae), rice weevils (Coleoptera: Curculionidae), and red flour beetles (Coleoptera: Tenebrionidae) in stored wheat. Eco. Entmol., 85, 570-575.

Arthur, F. H. (1996). Grain protectants: Current status and prospects for the future. Stored Prod. Res., 32, 293-302.

Athanassiou, C. G., Papagregorioub, A. S. and Buchelos, C. (2004). Insecticidal and residual effect of three pyrethroids against sitophilus oryzae (L.) (Coleoptera: Curculionidae) on stored wheat. Stored Prod. Res., 40, 289-297.

Battu, R. S., Singh, B., Chahal, K. K. and Kalra, R. L. (1996). Contamination of animal feed with residues of $\mathrm{HCH}$ and DDT. Pesti. Res., 8(2), 172 175.

Biddle, G.N. (1982). Toxicology of lead: Primer for Analytical Chemists. Association and Official Analytical Chemistry, (65), 947-952.

Cabrera, C., M.L. Lorenzo, and M.C. Lopez. (1995). Lead and cadmium contamination in dairy products and its repercussion on total dietary intake. Food Chem., (43), 1605-1609.

Correia, M., Delerue-Matos, C., and Alves, A. (2000). Multi-residue methodology for pesticide screening in wines. Chromatogr.A, 889, 5967.Codex Guidelines vol. 2; 1993

Dogeim, S.M., S.A. Gadalla, E. Y. Salama, A. M. El-Marsafy, and Y. M. Nabil, (2002). Monitoring of pesticide residues in Egyptian fruits and vegetables during 1997. Food Additive and Contaminants, 19(11), 1015-1027.

Dunnick, J. K. and Fowler, B.A. (1988). Cadmium: In 'Handbook on Toxicity of Inorganic Compounds', (H.G. Seiler, H. Sigel, A. Sigel, eds), Marcel Deccer Inc., New Yourk and Baasel, 155-174.

Fytianos, K., Vasilikiotis, G., Weil, L., Kavlendis, E. and Laskaridis, N. (1985). Preliminary study of organochlorine compounds in milk products, human milk and vegetables. Bull. Environ. Contam. Toxicol., 34, 504508. 
Giannou, V., Kessoglou, V. and Tzia, C. (2003). Quality and safety characteristics of bread made from frozen dough. Trends Food Sci. Tech., 14, 99-108.

Hubbard, A.H., and D.G. Lindsay. (1979): Dietary intakes of heavy metals by consumers in the UK, in: Proceedings of the International Conference on Management and Control of Heavy Metals in the Environment, London, 52-55.

Johnson, R. D., and Manske, D. D. (1977). Pesticides in food and feed. Pesti. Monit, 11(3), 116-131.

Joint FAO/ WHO Expert Committee on Food Additives, (2005). Summary of Evaluations Performed by the Joint FAO/ WHO Expert Committee on Food Additives (JECFA 1956-2003), (First through sixty- first meetings). Food and Agriculture Organization of the United Nations and the World Health Organization, ILSI Press International Life Science Institute, Washington, DC.

Kihlberg, I., Johansson, L., Kohler, A. and Risvik, E. (2004). Sensory qualities of whole wheat pan bread-influence of farming system, milling and baking technique, Cereal Sci., 39, 67-84.

Lalah, O. J .and Wandiga, S. O. (2002). The effect of boiling on the removal of persistent malathion residues from stored grains, Stored Prod. Res., 38, 1-10.

Llobet J. M., S. Granero, M. Schumacher, J. Corbella, and J. L. Domingo, (1998). Biological monitoring of environmental pollution and human exposure to metals in Tarragona, Spain. IV. Estimation of dietary intake, Trace Elements. 15 (3), 136-141.

Lodovici M. M., P. Dolara, C. Casalini, S. Cipillano, and G. Testolin. (1995). Polyclic aromatic hydrocarbon contamination in the Italian diet. Food Addit. Contam. 12(5), 703-713.

Luck, M. A., J.E Froberg, G. M Doose, and H.T. Masumato, (1981). Improved multiresidues gas chromatographic determination of organo phosphorous, organonitrogen and organohalogen pesticides in products using flame photometric and electrolytic conductivity detectors. Journal of the Association of Official Analytical chemists, 64, 1187-1195.

Mukherjee, D., Roy, B. R., Chakra- borty, J. and Ghosh, B. N., (1980). Pesticide residues in human food in Calcutta. Ind. J. Med. Res., 72, 577-582.

NMKL, (1991). Technical Nordisk Metodikkommitte for Livsmede Nordic Committee on Food Analysis Technical Research Centre of Finland, Method (VTT-4319).

Robards, K. and Worsfold, P., (1991). Cadmium toxicology and analysis, A Review. Analyst. 116, 549-568.

Stathers, T. E., Chigariror, J., Mudiwa, M., Mvumi, B. M. and Golob, P., (2002). Small-scale farmer perceptions of diatomaceous earth products as potential stored grain protestants in Zimbabwe. Crop Protect., 21, 1049-1060. 
Suzuki, T., N Ishikaw,. Sato and Sakalk, (1979). Determination of chlorinated pesticide residues in foods. Rapid screening method for chlorinated pesticides in milk, Journal Association of Official Analytical chemists 62(3), 681-684.

Tati, M., Katagiri, Y. and Kawai, M. (1976). Urinary and fecal excretion of cadmium in normal Japanase: An Approach to Non- Toxic levels of cadmium. In 'Effects and Dose- Response Relationships of Toxic Metals' (G. F. Nordberg, ed.), Elsevier Sci, Pub. Comp, Amsterdam, 309-330.

Vaidya, P. K., Goyal, K. C. and Singh, V., (1991). Evaluation of endosulfan residue in okra (Abelmoschus esculantus) fruit. Ad. Bios., 10(11), 107-110.

Weidner, H. A. (1989). Survey of research into stored products protection in countries of the third world. Plant Res. Dev., 25, 22-50.

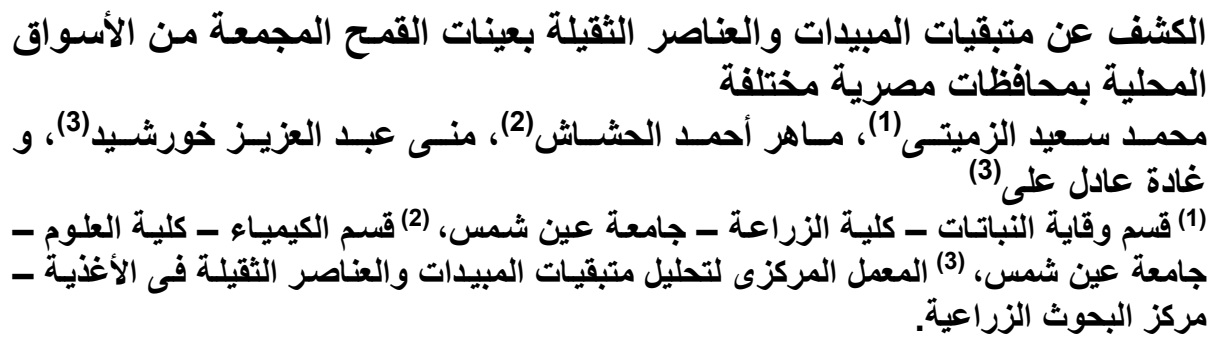

تم تجميع 155 عنية قمح من أسواق محلية بعشر محافظات مصرية. وقد خضعت هذه العينات جميعاً.

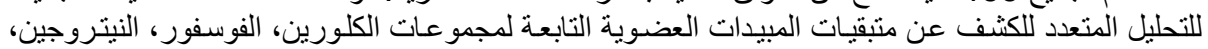

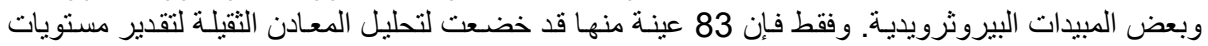

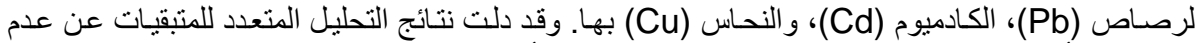

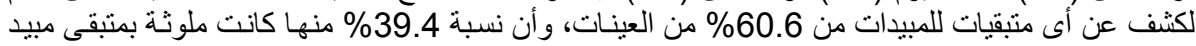

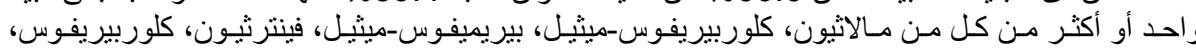

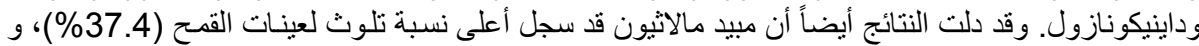

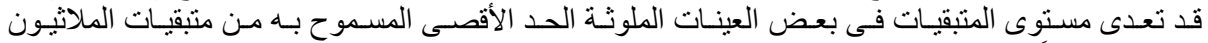
(2.6\%) تبعاً لمو اصفات الكودكس (0.5 مجم/كجم).

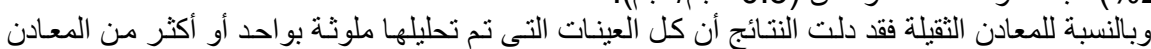

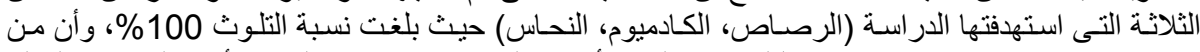
بينها نسبة 18.1\% قد تعدى مستوى التلوث بها الحد الأقصى المسموح بها، وكان النحاس أكثر العناصر الثقيلة

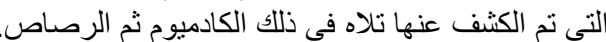

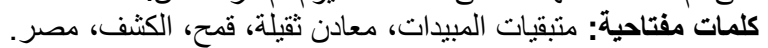

كلية الزراعة - جامعة المنصورة

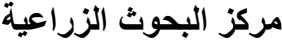

قام بتحكيم البحث

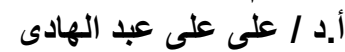

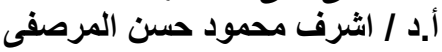


El-Zemaity, M. S. et al. 
Table (3): Minimum, maximum, mean values of pesticide residues together with the frequency, number and percentage of contaminated and violated wheat samples collected from different Egyptian governorates

\begin{tabular}{|c|c|c|c|c|c|c|c|c|c|c|c|c|}
\hline \multirow[t]{2}{*}{ Governorate } & \multirow[t]{2}{*}{$\begin{array}{l}\text { Total No. } \\
\text { of samples }\end{array}$} & \multicolumn{2}{|c|}{ Contaminated Samples } & \multirow[t]{2}{*}{$\mid \begin{array}{l}\text { Detected } \\
\text { Pesticides }\end{array}$} & \multicolumn{2}{|c|}{$\begin{array}{c}\text { Contaminated } \\
\text { samples with } \\
\text { each } \\
\text { pesticide }\end{array}$} & \multirow[t]{2}{*}{$\begin{array}{l}\text { Min. } \\
(\mathbf{m g} / \mathbf{k g})\end{array}$} & \multirow[t]{2}{*}{$\begin{array}{c}\text { Max. } \\
(\mathrm{mg} / \mathrm{kg})\end{array}$} & \multirow[t]{2}{*}{$\begin{array}{l}\text { Mean } \\
(\mathrm{mg} / \mathrm{kg})\end{array}$} & \multirow[t]{2}{*}{$\begin{array}{c}\text { MRL } \\
(\mathrm{mg} / \mathrm{kg})\end{array}$} & \multicolumn{2}{|c|}{$\begin{array}{l}\text { Violated } \\
\text { compound }\end{array}$} \\
\hline & & No. & $\%$ & & No. & $\%$ & & & & & No. & $\%$ \\
\hline Beni Suef & 8 & 2 & 25 & Malathion & 2 & 100 & 0.06 & 0.16 & 0.11 & 0.5 & 0 & 0 \\
\hline \multirow{3}{*}{ Cairo } & \multirow{3}{*}{31} & \multirow{3}{*}{7} & \multirow{3}{*}{22.6} & Malathion & 6 & 85.7 & 0.05 & 0.12 & 0.065 & 0.5 & 0 & 0 \\
\hline & & & & Chlorpyrifos-Me & 3 & 42.9 & 0.05 & 0.1 & 0.067 & 10 & 0 & 0 \\
\hline & & & & Fenitrothion & 1 & 14.3 & 0.05 & 0.05 & 0.05 & [10] & 0 & 0 \\
\hline \multirow[b]{2}{*}{ Damietta } & \multirow[b]{2}{*}{5} & \multirow[b]{2}{*}{2} & \multirow{2}{*}{40} & Malathion & 2 & 100 & 0.05 & 0.13 & 0.09 & 0.5 & 0 & 0 \\
\hline & & & & Chlorpyrifos-Me & 1 & 50 & 0.09 & 0.09 & 0.09 & 10 & 0 & 0 \\
\hline \multirow{2}{*}{ Fayoum } & \multirow[b]{2}{*}{4} & \multirow[b]{2}{*}{3} & \multirow[b]{2}{*}{75} & Malathion & 3 & 100 & 0.05 & 0.41 & 0.17 & 0.5 & 0 & 0 \\
\hline & & & & Chlorpyrifos-Me & 1 & 33.3 & 0.07 & 0.07 & 0.07 & 10 & 0 & 0 \\
\hline \multirow{4}{*}{ Gharbiya } & \multirow{4}{*}{9} & \multirow{4}{*}{3} & \multirow{4}{*}{33.3} & Malathion & 2 & 66.7 & 0.05 & 0.12 & 0.085 & 0.5 & 0 & 0 \\
\hline & & & & Chlorpyrifos-Me & 2 & 66.7 & 0.06 & 0.52 & 0.29 & 10 & 0 & 0 \\
\hline & & & & Permethrin & 1 & 33.3 & 0.2 & 0.2 & 0.2 & ** & $\begin{array}{ll}-- \\
\end{array}$ & --- \\
\hline & & & & Fenitrothion & 1 & 33.3 & 0.24 & 0.24 & 0.24 & [10] & 0 & 0 \\
\hline \multirow{4}{*}{ Giza } & \multirow{4}{*}{48} & \multirow{4}{*}{31} & \multirow{4}{*}{64.6} & Malathion & 30 & 96.8 & 0.05 & 2.1 & 0.28 & 0.5 & 3 & 6.25 \\
\hline & & & & Chlorpyrifos-Me & 9 & 29 & 0.05 & 0.42 & 0.146 & 10 & 0 & 0 \\
\hline & & & & Pirimiphos-Me & 3 & 9.68 & 0.03 & 0.2 & 0.09 & [10] & 0 & 0 \\
\hline & & & & Diniconazole & 1 & 3.2 & 3.2 & 3.2 & 3.2 & & --- & --- \\
\hline
\end{tabular}


Table (3) continued:

\begin{tabular}{|c|c|c|c|c|c|c|c|c|c|c|c|c|}
\hline \multirow[t]{2}{*}{ Governorate } & \multirow[t]{2}{*}{$\begin{array}{l}\text { Total No. } \\
\text { of samples }\end{array}$} & \multicolumn{2}{|c|}{ Contaminated Samples } & \multirow[t]{2}{*}{$\begin{array}{l}\text { Detected } \\
\text { Pesticides }\end{array}$} & \multicolumn{2}{|c|}{$\begin{array}{c}\text { Contaminated } \\
\text { samples with } \\
\text { each } \\
\text { pesticide }\end{array}$} & \multirow[t]{2}{*}{\begin{tabular}{|} 
Min. \\
$(\mathrm{mg} / \mathrm{kg})$
\end{tabular}} & \multirow[t]{2}{*}{$\begin{array}{c}\text { Max. } \\
(\mathrm{mg} / \mathrm{kg})\end{array}$} & \multirow[t]{2}{*}{$\begin{array}{l}\text { Mean } \\
(\mathrm{mg} / \mathrm{kg})\end{array}$} & \multirow[t]{2}{*}{$\begin{array}{c}\text { MRL } \\
(\mathrm{mg} / \mathrm{kg})\end{array}$} & \multicolumn{2}{|c|}{$\begin{array}{l}\text { Violated } \\
\text { compound }\end{array}$} \\
\hline & & No. & $\%$ & & No. & $\%$ & & & & & No. & $\%$ \\
\hline \multirow{2}{*}{ Ismailia } & \multirow[b]{2}{*}{14} & \multirow[b]{2}{*}{6} & \multirow[b]{2}{*}{42.9} & Malathion & 6 & 100 & 0.05 & 0.11 & 0.065 & 0.5 & 0 & 0 \\
\hline & & & & Chlorpyrifos-Me & 2 & 33.3 & 0.05 & 0.05 & 0.05 & 10 & 0 & 0 \\
\hline Minufiya & 8 & 1 & 12.5 & Malathion & 1 & 100 & 0.05 & 0.05 & 0.05 & 0.5 & 0 & 0 \\
\hline \multirow{2}{*}{ Qalyubiya } & \multirow[b]{2}{*}{14} & \multirow{2}{*}{3} & \multirow{2}{*}{21.4} & Malathion & 3 & 100 & 0.07 & 3.6 & 1.25 & 0.5 & 1 & 7.14 \\
\hline & & & & Chlorpyrifos-Me & 1 & 33.3 & 0.08 & 0.08 & 0.08 & 10 & 0 & 0 \\
\hline \multirow{2}{*}{ Sharkiya } & \multirow[b]{2}{*}{14} & \multirow[b]{2}{*}{4} & \multirow{2}{*}{28.6} & Malathion & 3 & 75 & 0.05 & 0.29 & 0.13 & 0.5 & 0 & 0 \\
\hline & & & & Chlorpyrifos & 1 & 25 & 0.05 & 0.05 & 0.05 & 0.5 & 0 & 0 \\
\hline Total & 155 & 61 & 39.4 & \begin{tabular}{|l|} 
Malathion \\
Chlorpyrifos-Me \\
Fenitrothion \\
Pirimifos-Me \\
Diniconazole \\
Chlorpyrifos
\end{tabular} & $\begin{array}{c}58 \\
16 \\
1 \\
3 \\
1 \\
1\end{array}$ & $\begin{array}{l}37.4 \\
10.3 \\
0.65 \\
1.94 \\
0.65 \\
0.65\end{array}$ & & & & & 4 & 2.6 \\
\hline
\end{tabular}

* = Maximum Residue Limit (MRL) issued by Codex Committee of Pesticide Residues (CCPR) (2008)

** $=$ MRL is not available

[ ] extrapolated on cereal grains 
Table (4): Minimum, maximum, mean values of heavy metals together with the frequency, number and percentage of contaminated and violated wheat samples collected from different Egyptian governorates.

\begin{tabular}{|c|c|c|c|c|c|c|c|c|c|c|c|c|c|c|}
\hline \multirow[t]{2}{*}{ Governorate } & \multirow{2}{*}{$\begin{array}{c}\text { Total No. } \\
\text { of } \\
\text { samples }\end{array}$} & \multicolumn{2}{|c|}{$\begin{array}{l}\text { Contaminated } \\
\text { Samples }\end{array}$} & \multirow[t]{2}{*}{ Elements } & \multicolumn{2}{|c|}{$\begin{array}{l}\text { Contaminated } \\
\text { samples with } \\
\text { each element }\end{array}$} & \multirow{2}{*}{$\underset{(\mathrm{mg} / \mathrm{kg})}{\operatorname{Min} .}$} & \multirow{2}{*}{$\begin{array}{c}\text { Max. } \\
(\mathrm{mg} / \mathrm{kg})\end{array}$} & \multirow{2}{*}{$\begin{array}{c}\text { Mean } \\
(\mathrm{mg} / \mathrm{kg})\end{array}$} & \multirow{2}{*}{$\begin{array}{c}\mathrm{ML} \\
(\mathrm{mg} / \mathrm{kg})\end{array}$} & \multicolumn{2}{|c|}{$\begin{array}{l}\text { Violated } \\
\text { element }\end{array}$} & \multicolumn{2}{|c|}{$\begin{array}{l}\text { Violated } \\
\text { samples }\end{array}$} \\
\hline & & No. & $\%$ & & No. & $\%$ & & & & & No. & $\%$ & No. & $\%$ \\
\hline \multirow{3}{*}{ Beni Suef } & \multirow{3}{*}{1} & \multirow{3}{*}{1} & \multirow{3}{*}{100} & $\mathrm{Cd}$ & $\overline{1}$ & 100 & 0.031 & 0.031 & 0.031 & 0.2 & 0 & 0 & \multirow{3}{*}{1} & \multirow{3}{*}{100} \\
\hline & & & & $\mathrm{Cu}$ & 1 & 100 & 4.1 & 4.1 & 4.1 & ** & -- & -- & & \\
\hline & & & & $\mathrm{Pb}$ & 1 & 100 & 0.23 & 0.23 & 0.23 & 0.2 & 1 & 100 & & \\
\hline \multirow{3}{*}{ Cairo } & \multirow{3}{*}{20} & \multirow{3}{*}{20} & \multirow{3}{*}{100} & $\mathrm{Cd}$ & 19 & 95 & 0.003 & 0.25 & 0.05 & 0.2 & 2 & 10.5 & \multirow{3}{*}{5} & \multirow{3}{*}{25} \\
\hline & & & & $\mathrm{Cu}$ & 20 & 100 & 0.22 & 9 & 4.78 & ** & -- & -- & & \\
\hline & & & & $\mathrm{Pb}$ & 12 & 60 & 0.04 & 0.5 & 0.122 & 0.2 & 5 & 25 & & \\
\hline \multirow{3}{*}{ Damietta } & \multirow{3}{*}{2} & \multirow{3}{*}{2} & \multirow{3}{*}{100} & $\mathrm{Cd}$ & 2 & 100 & 0.04 & 0.06 & 0.05 & 0.2 & 0 & 0 & \multirow{3}{*}{0} & \multirow{3}{*}{0} \\
\hline & & & & $\mathrm{Cu}$ & 2 & 100 & 3.9 & 4.8 & 4.35 & ** & -- & -- & & \\
\hline & & & & $\mathrm{Pb}$ & 0 & 0 & 0 & 0 & 0 & 0.2 & 0 & 0 & & \\
\hline \multirow{3}{*}{ Fayoum } & & & & $\mathrm{Cd}$ & 3 & 100 & 0.008 & 0.04 & 0.022 & 0.2 & 0 & 0 & & \\
\hline & 3 & 3 & 100 & $\mathrm{Cu}$ & 3 & 100 & 5 & 8.8 & 6.47 & ** & -- & -- & 1 & 33.3 \\
\hline & & & & $\mathrm{Pb}$ & 3 & 100 & 0.04 & 0.28 & 0.15 & 0.2 & 1 & 33.3 & & \\
\hline & & & & $\mathrm{Cd}$ & 6 & 100 & 0.004 & 0.015 & 0.05 & 0.2 & 0 & 0 & & \\
\hline Gharbiya & 6 & 6 & 100 & $\mathrm{Cu}$ & 6 & 100 & 2.63 & 11.2 & 5.82 & ** & -- & -- & 1 & 16.7 \\
\hline & & & & $\mathrm{Pb}$ & 4 & 67 & 0.022 & 0.22 & 0.103 & 0.2 & 1 & 16.7 & & \\
\hline & & & & $\mathrm{Cd}$ & 34 & 97 & 0.006 & 0.074 & 0.038 & 0.2 & 0 & 0 & & \\
\hline Giza & 35 & 35 & 100 & $\mathrm{Cu}$ & 35 & 100 & 0.92 & 12.1 & 4.98 & $* *$ & -- & -- & 3 & 8.6 \\
\hline & & & & $\mathrm{Pb}$ & 16 & 45.7 & 0.04 & 0.48 & 0.13 & 0.2 & 3 & 8.6 & & \\
\hline & & & & $\mathrm{Cd}$ & 8 & 80 & 0.002 & 0.13 & 0.033 & 0.2 & 0 & 0 & & \\
\hline Ismailia & 10 & 10 & 100 & $\mathrm{Cu}$ & 10 & 100 & 3.4 & 4.8 & 4.28 & ** & -- & -- & 1 & 10 \\
\hline & & & & $\mathrm{Pb}$ & 8 & 80 & 0.04 & 0.51 & 0.145 & 0.2 & 1 & 10 & & \\
\hline
\end{tabular}


Table (4) continued:

\begin{tabular}{|c|c|c|c|c|c|c|c|c|c|c|c|c|c|c|}
\hline \multirow[t]{2}{*}{ Governorate } & \multirow[t]{2}{*}{$\begin{array}{l}\text { Total No. } \\
\text { of samples }\end{array}$} & \multicolumn{2}{|c|}{$\begin{array}{c}\text { Contaminated } \\
\text { Samples }\end{array}$} & \multirow[t]{2}{*}{ Elements } & \multicolumn{2}{|c|}{$\begin{array}{l}\text { Contaminated } \\
\text { samples with } \\
\text { each element }\end{array}$} & \multirow[t]{2}{*}{$\underset{(\mathrm{mg} / \mathrm{kg})}{\operatorname{Min} .}$} & \multirow[t]{2}{*}{$\begin{array}{c}\text { Max. } \\
(\mathbf{m g} / \mathbf{k g})\end{array}$} & \multirow[t]{2}{*}{$\begin{array}{c}\text { Mean } \\
(\mathrm{mg} / \mathrm{kg})\end{array}$} & \multirow[t]{2}{*}{$M L(\mathrm{mg} / \mathrm{kg})$} & \multicolumn{2}{|c|}{$\begin{array}{l}\text { Violated } \\
\text { element }\end{array}$} & \multicolumn{2}{|c|}{$\begin{array}{l}\text { Violated } \\
\text { samples }\end{array}$} \\
\hline & & No. & $\%$ & & No. & $\%$ & & & & & No. & $\%$ & No. & $\%$ \\
\hline \multirow{3}{*}{ Minufiya } & \multirow{3}{*}{1} & \multirow{3}{*}{1} & \multirow{3}{*}{100} & $\mathrm{Cd}$ & 1 & 100 & 0.011 & 0.011 & 0.011 & 0.2 & 0 & 0 & \multirow{3}{*}{0} & \multirow{3}{*}{0} \\
\hline & & & & $\mathrm{Cu}$ & 1 & 100 & 7.7 & 7.7 & 7.7 & ** & -- & -- & & \\
\hline & & & & $\mathrm{Pb}$ & 1 & 100 & 0.1 & 0.1 & 0.1 & 0.2 & 0 & 0 & & \\
\hline \multirow{3}{*}{ Qalyubiya } & \multirow{3}{*}{4} & \multirow{3}{*}{4} & \multirow{3}{*}{100} & $\mathrm{Cd}$ & 4 & 100 & 0.002 & 0.018 & 0.011 & 0.2 & 0 & 0 & \multirow{3}{*}{2} & \multirow{3}{*}{50} \\
\hline & & & & $\mathrm{Cu}$ & 4 & 100 & 4.03 & 8.1 & 5.61 & $* \star$ & -- & -- & & \\
\hline & & & & $\mathrm{Pb}$ & 2 & 50 & 0.23 & 0.25 & 0.24 & 0.2 & 2 & 50 & & \\
\hline \multirow{3}{*}{ Sharkiya } & \multirow{3}{*}{1} & \multirow{3}{*}{1} & \multirow{3}{*}{100} & $\mathrm{Cd}$ & 1 & 100 & 0.062 & 0.062 & 0.062 & 0.2 & 0 & 0 & \multirow{3}{*}{1} & \multirow{3}{*}{100} \\
\hline & & & & $\mathrm{Cu}$ & 1 & 100 & 354 & 354 & 354 & $\star \star \star$ & --- & -- & & \\
\hline & & & & $\mathrm{Pb}$ & 1 & 100 & 4.8 & 4.8 & 4.8 & 0.2 & 1 & 100 & & \\
\hline \multirow[t]{3}{*}{ Total } & \multirow[t]{3}{*}{83} & \multirow[t]{3}{*}{83} & \multirow[t]{3}{*}{100} & $\mathrm{Cd}$ & 79 & 95.2 & & & & & 2 & 2.4 & \multirow[t]{3}{*}{15} & \multirow[t]{3}{*}{$\overline{18.1}$} \\
\hline & & & & $\mathrm{Cu}$ & 83 & 100 & & & & & - & - & & \\
\hline & & & & $\mathrm{Pb}$ & 48 & 57.8 & & & & & 15 & 18.1 & & \\
\hline
\end{tabular}

Maximum Limits (ML) of the heavy metals on wheat samples issued by the codex committee on Food Additive and Contaminants (CCFAC) (2008).

${ }_{* \star}:$ no ML established for $\mathrm{Cu}$ on wheat. 